\begin{tabular}{|l|l|l||}
\hline \multicolumn{2}{|c|}{ PublisherInfo } \\
\hline \hline PublisherName & $:$ & BioMed Central \\
\hline \hline PublisherLocation & $:$ & London \\
\hline \hline PublisherImprintName & $:$ & BioMed Central \\
\hline \hline
\end{tabular}

\title{
Budding interactome
}

\begin{tabular}{|l|l|l||}
\hline \multicolumn{2}{|c|}{ ArticleInfo } \\
\hline \hline ArticleID & $:$ & 4014 \\
\hline \hline ArticleDOI & $:$ & $10.1186 /$ gb-spotlight-20010315-01 \\
\hline \hline ArticleCitationID & $:$ & spotlight-20010315-01 \\
\hline \hline ArticleSequenceNumber & $:$ & 85 \\
\hline \hline ArticleCategory & $:$ & Research news \\
\hline \hline ArticleFirstPage & $:$ & 1 \\
\hline \hline ArticleLastPage & $:$ & 2 \\
\hline \hline & & RegistrationDate : 2001-03-15 \\
ArticleHistory & $:$ & OnlineDate \\
\hline \hline ArticleCopyright & $:$ & BioMed Central Ltd2001 $03-15$ \\
\hline \hline ArticleGrants & $:$ & \\
\hline \hline ArticleContext & $:$ & 130592211 \\
\hline \hline
\end{tabular}




\section{Jonathan B Weitzman}

Email: jonathanweitzman@hotmail.com

Functional genomics aims to turn genomic information into a comprehensive understanding of the workings of the cell at the molecular level. It is assumed that extensive knowledge of the interactions between proteins will contribute significantly to this goal. In the Early Edition of Proceedings of the National Academy of Sciences, Ito et al. describe the results of a comprehensive high-throughput screen to identify all the protein-protein interactions (the 'interactome') in the budding yeast Saccharomyces cerevisiae. They used the yeast two-hydrid approach to screen 'bait' proteins representing the entire 6000 proteins encoded by the yeast genome. They identified 4,549 interactions between 3,278 proteins. Among the interactions are subnetworks implicated in distinct biological events, such as spindle-polebody function, autophagy and vesicular transport. Less than $20 \%$ of these interactions overlap with those identified in an independent screen, emphasizing the experimental limitations of the methodology and the difficulty in obtaining fully comprehensive datasets.

\section{References}

1. Proteomics to study genes and genomes.

2. Proceedings of the National Academy of Science, [http://www.pnas.org]

3. Toward a protein-protein interaction map of the budding yeast: A comprehensive system to examine two-hybrid interactions in all possible combinations between the yeast proteins.

4. A comprehensive two-hybrid analysis to explore the yeast protein interactome, [http://www.pnas.org/cgi/doi/10.1073/pnas.061034498]

5. A novel genetic system to detect protein-protein interactions.

6. Yeast Interacting Proteins Database, [http://genome.c.kanazawa-u.ac.jp/Y2H]

7. A comprehensive analysis of protein-protein interactions in Saccharomyces cerevisiae.

This PDF file was created after publication. 